\title{
PINSA Learning Media (Cow Digestion Billboard) on Healthy Food Theme
}

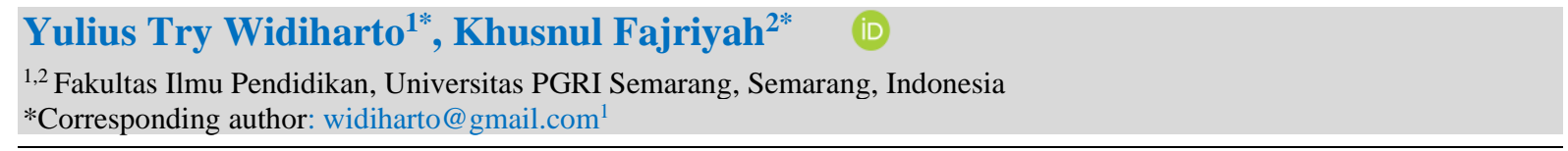

\begin{abstract}
Abstrak
Belum dikembangkannya media pembelajaran interaktif dengan memanfaatkan media visual, sehingga siswa mengalami kesulitan pembelajaran yang bersifat abstrak. Siswa kurang memahami materi pada saat proses pembelajaran berlangsung. Tujuan penelitian ini yaitu mengembangkan media papan iklan pencernaan sapi dapat digunakan sebagai alternative media untuk membantu proses pembelajaran. Jenis penelitian ini adalah penelitian dan pengembangan ( $\& \& D)$ dengan model pengembangan yang digunakan yaitu model ADDIE. Responden dalam penelitian ini adalah 6 guru dan 58 siswa kelas $V$ sekolah dasar. Penelitian ini melibatkan 3 orang ahli materi dan 3 orang ahli media pembelajaran. Teknik yang digunakan dalam mengumpulkan data yaitu wawancara, observasi, angket dan dokumentasi. Instrument yang digunakan yaitu kuesioner. Teknik analisis data yang digunakan adalah kuantitatif dan kualitatif. Hasil penelitian ini diperoleh berdasarkan hasil uji kevalidan dari penilaian validator ahli media dengan skor 99\% (sangat baik), ahli materi pembelajaran 98\% (sangat baik). Hasil uji kepraktisan diperoleh berdasarkan penilaian respon guru sebesar 94\% (sangat baik) dan siswa sebesar 99\% (sangat baik). Dapat disimpulkan bahwa media papan iklan pencernaan sapi valid dan praktis digunakan pada tema makanan sehat subtema bagaimana tubuh mengolah makanan untuk siswa kelas V sekolah dasar.
\end{abstract}

Kata kunci: Media pembelajaran, PINSA, Sekolah Dasar

\section{Abstract}

Interactive learning media has not yet been developed by utilizing visual media to experience abstract learning difficulties. Students do not understand the material during the learning process. This study aims to develop a media billboard for cow digestion that can be used as an alternative media to help the learning process. This type of research is research and development (R\&D), with the development model used being the ADDIE model. Respondents in this study were six teachers and 58 fifth-grade elementary school students. This study involved three material experts and three learning media experts. The techniques used in collecting data are interviews, observations, questionnaires, and documentation. The instrument used is a questionnaire. The data analysis technique used is quantitative and qualitative. The results of this study were obtained based on the validity test results from the assessment of the media expert validator with a score of $99 \%$ (excellent), learning material expert 98\% (excellent). The results of the practicality test were obtained based on the teacher's response assessment of $94 \%$ (excellent) and $99 \%$ of students (excellent). It can be concluded that the beef digestive billboard media is valid and practical to use on the theme of healthy food, the sub-theme of how the body processes food for fifthgrade elementary school students.

Keywords: Learning media, PINSA, Elementary School

\begin{tabular}{|c|c|c|}
\hline History: & & Publisher: Undiksha Press \\
\hline Received & : December 15, 2020 & Licensed: This work is licensed under \\
\hline Revised & : January 21, 2021 & a Creative Commons Attribution 3.0 License \\
\hline Accepted & : June 10, 2021 & (c) (7) (2) \\
\hline Published & : July 25, 2021 & (U) ${ }_{E Y}{ }_{S A}$ \\
\hline
\end{tabular}

\section{Introduction}

Indonesian education uses the 2013 curriculum (Suwana et al., 2013; Thoyyibah et al., 2019). The 2013 curriculum emphasizes the modern dimension in learning using a scientific approach, whose learning focuses more on observing, asking questions, reasoning, trying, and forming networks jejaring (Anif et al., 2020; Wulandari, 2020). In addition, the 2013 curriculum concept considers students as learning centers (Student-centered) (Anif et al., 2020; Suyanto, 2018). This curriculum emphasizes the meaningful learning experience of students to explore their own desired knowledge with various learning resources in the surrounding environment (Fahmy et al., 2015; Wiranto \& Slameto, 2021). Conceptually, the 2013 curriculum will bring significant changes. Thus, formal educational institutions such as 
schools continue to improve their systems and structures (Maharani, 2015; Suyanto, 2018). These changes are made, of course, for better education.

The learning process must be held interactively and fun to motivate students to participate actively (Backfisch et al., 2020; Lasagabaster, 2017). It causes the learning process to be supported by utilizing interesting learning resources and materials (Huang et al., 2020; Kocaj et al., 2018; Mesters et al., 2017). One of them is by engaging media (Ardhaoui et al., 2021; Partovi \& Razavi, 2019). The availability of learning resources by the 2013 curriculum is crucial. The existence of learning resources such as learning media can help students achieve learning goals (Asrial et al., 2020; Guswara, 2020; Tse et al., 2019). Therefore, the creativity of teachers in the use of media must be improved. In preparing to learn, teachers are also required to prepare easy delivery of information or learning materials and learning media that can convey that information or material (Bal-Taştan et al., 2018; Brandmiller et al., 2020; Teng, 2019).

According to the results of the analysis conducted by interviewing elementary schools with fifth-grade teachers at SD Negeri 02 Karanggondang, SD Negeri 01 Bondo, and SD Bopkri 03 Bondo, there are problems faced, namely the lack of learning media so that teachers in explaining the material still use conventional methods, namely lectures. The teacher finds it difficult to relate some material so that students more often record the material and then work on the questions, and the teacher does not yet have relevant media to support student understanding. Lack of varied media makes students' concentration on learning less (Layona et al., 2017; Priantini, 2020). As a result, students find it challenging to understand the material that has been delivered by the teacher (Satyawan, 2018; Zhang et al., 2016). Students focus on the material on average for only 10-15 minutes. Students sometimes do things that are not by learning activities. For example, students are fantastic at talking to themselves with their classmates, drawing things that do not match the material, and even ignoring the teacher during learning. Therefore, the learning objectives are not optimal. One way that can be used to overcome these problems is to apply learning by using media as a tool to solve problems that are of interest to students (Kamelia, 2019; Megawati \& Utami, 2020; Shao \& He, 2020).

The results of the analysis of student needs through a questionnaire stated that the teacher had not used learning media on the theme of healthy food. According to students, using the media will help them understand the cow's digestive system material. Students tend to like concrete media because it is more interesting to look at, easy to recognize the original form, and helps clarify the material. So it can be concluded that learning media plays a role in helping students to get direct experience and encouraging student enthusiasm in the teaching and learning process ((Marino \& Crocco, 2020; Mukuka et al., 2021; Sriani et al., 2015). It makes students quickly grasp the material and can find the correct answer according to the material that has been studied (Febliza \& Okatariani, 2020; Jogezai et al., 2021; Sunismi, 2015). The use of media is necessary to facilitate the absorption of material for students (Chen \& Li, 2011; Kartika et al., 2019; Ristanti \& Arianto, 2019). Learning media is an important part that must be considered for teachers. Media is a place for messages (Agung et al., 2017; Hamid et al., 2017). Media is also a tool that conveys or delivers learning messages (Rahayuningsih, 2020; Suryanda et al., 2019). So it can be concluded that good media is also needed to get good learning with the messages in the learning being conveyed to the maximum.

The previous research findings stated that learning media could make it easier for students to understand learning materials (Abror et al., 2020; Lai \& Tai, 2021; Ntobuo et al., 2018). Other research findings also state that learning media can increase student enthusiasm in learning to improve student learning outcomes (Budiarto et al., 2020; Darmaji et al., 2019; Samsudin et al., 2019). It can be concluded that learning media can increase students' 
learning motivation. There is no study on the development of learning media PINSA (Cow Digestion Advertising Board) on theme 3 Healthy Food. The advantage of this media is that the media to be developed contains examples of images that make it easier for students to understand the subject matter. The purpose of this study is to develop learning media PINSA (Cow Digestion Advertising Board) on the theme 3 Healthy Food. It is hoped that the PINSA learning media (Cow Digestion Advertising Board) can improve students' abilities.

\section{Methods}

This type of research uses research and development (R\&D) methods. The research and development procedure uses the ADDIE development model (Analysis, Design, Development, Implementation, and Evaluation). The ADDIE procedure has several stages, which are presented in Figure 1.

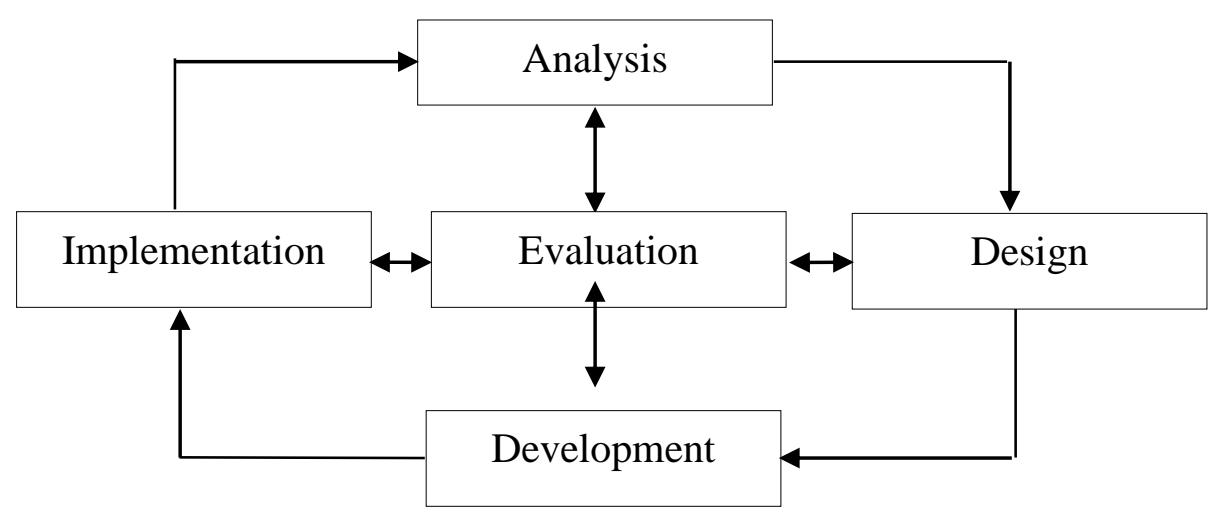

Figure 1. ADDIE Model Procedure (Agustien et al., 2018)

Test requirements analysis of research and development can be seen from the expert validator assessment results that have been met. In this study, media expert validators and material expert validators are needed as assessors in media development. This study uses quantitative data analysis techniques and qualitative data analysis. Quantitative data in this study were in the form of assessment scores of media experts, material experts, teacher, and student responses. At the same time, the qualitative data in this study are suggestions for improvement and comments from material experts and media experts. The data was obtained by filling out a questionnaire, then the data collected was analyzed using a score calculation based on the data obtained. Decision-making is needed as an indicator of success through the validation of media experts and material experts. For the media expert test and the material expert test. Each result per item is said to be valid if the results lie in the range of $81 \%-100 \%$ with the criteria of "very good." The range of $61 \%-80 \%$ with the criteria of "good" or in the range of 41\%-60\% with "enough" criteria.

\section{Results and Discussion Results}

Based on its development, the beef digestive fish board media was developed using the ADDIE procedure, namely analysis, design, development, implementation, and evaluation. In knowing the validity of the media, the media will be validated by media expert validators and material experts, while finding out the practicality of the media can be obtained through the results of the teacher and student questionnaire responses. The validity 
of the media can be seen from the results of the percentage validation of media experts and material experts. The results of the validation can be seen below.

From the results of the first stage of the media expert validation assessment carried out by the media expert validator, the average percentage of product assessment can be seen. Based on the results of data analysis, the average percentage of the first stage of media expert assessment is $82 \%$, so that the beef digestive billboard media is included in the "Very Good" criteria. Product rating percentage. Based on the results of data analysis, the average percentage of the first stage material expert assessment is $81 \%$, so the media material for the digestive beef billboard is included in the "Very Good" criteria.

From the results of the second stage of the media expert validation assessment carried out by the media expert validator, the average percentage of product evaluation can be seen. The results of data analysis showed that the average percentage of the second stage of media expert assessment was $99 \%$, so the beef digestive billboard media was included in the "Very Good" criteria. From the results of the second stage material expert carried out by the material expert validator, the average percentage of product assessment can be seen. The results of data analysis showed that the average percentage of the second stage material expert assessment was $98 \%$, so the media material for the cow digestive billboard was included in the "Very Good" criteria. Based on the results of the second stage of the media expert validation assessment, the average percentage result was $99 \%$ with the criteria of "Very Good." From the second stage of the material expert validation, the average percentage result was $98 \%$ with the "Very Good" criteria. So the cow digestive billboard media development is valid for use on the theme of healthy food, the sub-theme of how the body processes food for first grade $\mathrm{V}$ elementary school.

Based on the results of the responses of the fifth-grade teachers, there were three fifthgrade teachers. The ideal percentage average was $94 \%$, so that the beef digestive billboard media was included in the "Very Good" criteria. Based on the results of student responses through student response questionnaires aimed at all fifth-grade students at SD $\mathrm{N} 02$ Karanggondang totaling 25 students, SD N 1 Bondo totaling 17 students, and SD Bopkri 03 Bondo totaling 16 students. The calculation results obtained an average ideal percentage of 99\% so that the media for digestive beef billboards is included in the "Very Good" criteria. So it can be concluded that the development of the cow digestive billboard media is practically used on the theme of healthy food, the sub-theme of how the body processes food for first grade learning for grade V Elementary School.

\section{Discussion}

The cow digestive billboard media is suitable for use in the learning process because it is practical. Learning media is one component of communication, which functions as a channel for messages from teachers to students so that they are practical (Koesoemadinata, 2018; Reis et al., 2021). Learning media is a tool for teaching and learning (Febliza \& Okatariani, 2020; Sunismi, 2015). It makes it easier for students to understand learning materials when teachers use learning media (Jogezai et al., 2021; Kivunja, 2015). One factor determining the success of learning is the suitability of the media with the subjects being taught (Kartika et al., 2019; Yuliani et al., 2020). It causes students to absorb the information presented in learning media (Hamid et al., 2017; Ristanti \& Arianto, 2019).In addition, other media functions are to provide a more concrete picture or explanation (Rahayuningsih, 2020; Shohel \& Kirkwood, 2012). Engaging media will increase students' motivation in learning.

The PINSA media (cow digestion billboard) was developed according to the characteristics of students and subject matter to make it easier for students to learn. The message conveyed is poured into visual communication symbols (Liu et al., 2021; Rosidah, 2016). The images used are clear, attractive, easy to understand to stimulate students in 
learning (Fransisca \& Isak, 2016; Koesoemadinata, 2018). The advantage of image media is that it can provide details in the form of pictures so that students can remember them better than the verbal method (Michelsanti et al., 2019; Wusqo et al., 2021). In addition, image media can also solve problems that exist in oral/verbal media, namely in terms of limited memory in telling stories or explaining things (Larue \& Watling, 2021; Nafis, 2016).

The findings of previous research also stated that image media would make it easier for students to understand the subject matter (Dwiasih \& Agung, 2021; Taufiq et al., 2020). Other research findings also state that media presented with the characteristics of teaching materials and students will make it easier for students to learn so that it has an impact on increasing student learning outcomes (Aggleton, 2019; Enteria \& Casumpang, 2019; Ntobuo et al., 2018). It can be concluded that image media will facilitate students in learning. This research implies that the learning media developed in the form of PINSA Media (cow digestive billboard) can be used by teachers in teaching to increase students' enthusiasm and motivation to learn. It will have an impact on improving student learning outcomes.

\section{Conclusion}

The beef digestive billboard media get excellent qualifications from experts, teachers, and students. It can be concluded that the beef digestive billboard media can be applied in the learning process because it can help students learn.

\section{References}

Abror, M., Suryani, N., \& Ardianto, D. T. (2020). Digital Flipbook Empowerment as A Development Means for History Learning Media. JPI (Jurnal Pendidikan Indonesia), 8(2), 266. https://doi.org/10.23887/jpi-undiksha.v8i2.24122

Aggleton, J. (2019). Defining digital comics: a British Library perspective. Journal of Graphic Novels and Comics, 10(4), 393-409. https://doi.org/10.1080/21504857.2018.1503189

Agung, A. A. G., Widiana, I. W., \& Indrasuari, N. K. S. (2017). Pengembangan Aktivitas Pembelajaran Mengasosiasi Berbasis Media Gambar Berseri Dalam Meningkatkan Proses Kognitif Siswa. Jurnal Ilmiah Sekolah Dasar, 1(3), 138. https://doi.org/10.23887/jisd.v1i3.10323

Agustien, R., Umamah, N., \& Sumarno, S. (2018). Pengembangan Media Pembelajaran Video Animasi Dua Dimensi Situs Pekauman di Bondowoso Dengan Model Addie Mata $\begin{array}{llllll}\text { Pelajaran Sejarah Kelas X IPS. Jurnal Edukasi, } 19 . & \text { 5(1), }\end{array}$ https://doi.org/10.19184/jukasi.v5i1.8010

Anif, S., Sutopo, A., \& Prayitno, H. J. (2020). Lesson study validation: Model for social and natural sciences teacher development in the implementation of national curriculum in Muhammadiyah schools, Indonesia. Universal Journal of Educational Research, 8(1), 253-259. https://doi.org/10.13189/ujer.2020.080132

Ardhaoui, K., Lemos, M. S., \& Silva, S. (2021). Effects of new teaching approaches on motivation and achievement in higher education applied chemistry courses: A case study in Tunisia. Education for Chemical Engineers, 36. https://doi.org/10.1016/j.ece.2021.05.004

Asrial, Syahrial, Maison, M., Kurniawan, D. A., \& Piyana, S. O. (2020). Ethnoconstructivism E-Module to Improve Perception, Interest, And Motivation of Students in Class V Elementary School. Jurnal Pendidikan Indonesia, 9(1), 30-41. https://doi.org/10.23887/jpi-undiksha.v9i1.19222

Backfisch, I., Lachner, A., Hische, C., Loose, F., \& Scheiter, K. (2020). Professional 
knowledge or motivation? Investigating the role of teachers' expertise on the quality of technology-enhanced lesson plans. Learning and Instruction, 66. https://doi.org/10.1016/j.learninstruc.2019.101300

Bal-Taştan, S., Davoudi, S. M. M., Masalimova, A. R., Bersanov, A. S., Kurbanov, R. A., Boiarchuk, A. V, \& Pavlushin, A. A. (2018). The Impacts of Teacher's Efficacy and Motivation on Student's Academic Achievement in Science Education among Secondary and High School Students. EURASIA Journal of Mathematics, Science and Technology Education, 14(6), 2353-2366. https://doi.org/10.29333/ejmste/89579

Brandmiller, C., Dumont, H., \& Becker, M. (2020). Teacher Perceptions of Learning Motivation and Classroom Behavior: The Role of Student Characteristics. $\begin{array}{llll}\text { Contemporary Educational Psychology, } & \text { 63, }\end{array}$ https://doi.org/10.1016/j.cedpsych.2020.101893

Budiarto, M. K., Joebagio, H., \& Sudiyanto, S. (2020). Student's View of Using Digital Learning Media in Classroom Activities: A Case of Public Senior High School in Cirebon, Indonesia. Jurnal Pendidikan Progresif, 10(1). https://doi.org/10.23960/jpp.v10.i1.202006

Chen, E., \& Li, Z. (2011). On the application of multimedia technology in foreign language teaching and learning in China's colleges: Challenges, problems and implications. 2011 International Conference on Multimedia Technology, ICMT 2011, 595-597. https://doi.org/10.1109/ICMT.2011.6001903

Darmaji, Kurniawan, D. A., Astalini, Lumbantoruan, A., \& Samosir, S. C. (2019). Mobile learning in higher education for the industrial revolution 4.0: Perception and response of physics practicum. In International Journal of Interactive Mobile Technologies (Vol. 13, Issue 9). https://doi.org/10.3991/ijim.v13i09.10948

Dwiasih, A. A. I., \& Agung, A. A. G. (2021). The Development of Fabel E-Comic in Bahasa Indonesia Lesson for Grade II of Elementary School. Advances in Social Science, Education and Humanities Research. https://doi.org/10.2991/assehr.k.210407.284

Enteria, O., \& Casumpang, P. F. H. (2019). Effectiveness of Developed Comic Strips as Intructional Materials in Teaching Specific Science Concepts. International Journal for Innovation Education and Research, 7(10), 876-882. https://doi.org/10.31686/ijier.vol7.iss10.1835

Fahmy, R., Bachtiar, N., Rahim, R., \& Malik, M. (2015). Measuring Student Perceptions to Personal Characters Building in Education: An Indonesian Case in Implementing New Curriculum in High School. Procedia - Social and Behavioral Sciences, 211. https://doi.org/10.1016/j.sbspro.2015.11.112

Febliza, A., \& Okatariani, O. (2020). The Development of Online Learning Media by Using Moodle for General Chemistry Subject. Journal of Educational Science and Technology (EST), 6(1), 40. https://doi.org/10.26858/est.v6i1.12339

Fransisca, F., \& Isak, Y. R. (2016). Perancangan Aplikasi Alat Bantu Ajar Tebak Gambar Dengan Visual Studio 2010 Pada Sekolah Dasar Perguruan Buddhi. Jurnal Sisfokom, 5(1). https://doi.org/10.32736/sisfokom.v5i1.27

Guswara, A. M. (2020). The Contribution of Google Classroom Application and Motivation to The Learning Outcomes of Web Programming. Educational Technology, 4(4), 1-9. https://doi.org/10.23887/jet.v4i4.29896

Hamid, M. A., Aribowo, D., \& Desmira, D. (2017). Development of learning modules of basic electronics-based problem solving in Vocational Secondary School. Jurnal Pendidikan Vokasi, 7(2), 149. https://doi.org/10.21831/jpv.v7i2.12986

Huang, S.-Y., Kuo, Y.-H., \& Chen, H.-C. (2020). Applying Digital Escape Rooms Infused with Science Teaching in Elementary School: Learning Performance, Learning Motivation, and Problem-Solving Ability. Journal Pre-Proof, 1-46. 
https://doi.org/10.1016/j.tsc.2020.100681

Jogezai, N. A., Baloch, F. A., Jaffar, M., Shah, T., Khilji, G. K., \& Bashir, S. (2021). Teachers' attitudes towards social media (SM) use in online learning amid the COVID19 pandemic: the effects of SM use by teachers and religious scholars during physical distancing. Heliyon, 7(4). https://doi.org/10.1016/j.heliyon.2021.e06781

Kamelia, K. (2019). Using Video as Media of Teaching in English Language Classroom: Expressing Congratulation and Hopes. Utamax: Journal of Ultimate Research and Trends in Education, 1(1), 34-38. https://doi.org/10.31849/utamax.v1i1.2742

Kartika, Y., Wahyuni, R., Sinaga, B., \& Rajagukguk, J. (2019). Improving Math Creative Thinking Ability by using Math Adventure Educational Game as an Interactive Media. Journal of Physics: Conference Series, 1179(1), 1-6. https://doi.org/10.1088/17426596/1179/1/012078

Kivunja, C. (2015). Unpacking the Information, Media, and Technology Skills Domain of the New Learning Paradigm. International Journal of Higher Education, 4(1). https://doi.org/10.5430/ijhe.v4n1p166

Kocaj, A., Kuhl, P., Jansen, M., Pant, H. A., \& Stanat, P. (2018). Educational placement and achievement motivation of students with special educational needs. Contemporary Educational Psychology, 55. https://doi.org/10.1016/j.cedpsych.2018.09.004

Koesoemadinata, M. I. P. (2018). Visual Adaptation Of Wayang Characters In Teguh Santosa's Comic Art. MUDRA: Jurnal Seni Budaya, 33(3). https://doi.org/10.31091/mudra.v33i3.544

Lai, C., \& Tai, C.-P. (2021). Types of social media activities and Hong Kong South and Southeast Asians Youth's Chinese language learning motivation. System, 97. https://doi.org/10.1016/j.system.2020.102432

Larue, G. S., \& Watling, C. N. (2021). Acceptance of visual and audio interventions for distracted pedestrians. Transportation Research Part F: Traffic Psychology and Behaviour, 76. https://doi.org/10.1016/j.trf.2020.12.001

Lasagabaster, D. (2017). Language Learning Motivation and Language Attitudes in Multilingual Spain From an International Perspective. The Modern Language Journal, 101(3), 583-596. https://doi.org/10.1111/modl.12414

Layona, R., Yulianto, B., \& Turnadi, Y. (2017). Authoring Tool for Interactive Video Content for Learning Programming. Procedia Computer Science, 116, 37-44. https://doi.org/10.1016/j.procs.2017.10.006

Liu, D., Liang, C., Chen, S., Tie, Y., \& Qi, L. (2021). Auto-encoder based structured dictionary learning for visual classification. Neurocomputing, 438. https://doi.org/10.1016/j.neucom.2020.09.088

Maharani, Y. S. (2015). Efektivitas Multimedia Pembelajaran Interaktif Berbasis Kurikulum 2013. Indonesian Journal of Curriculum and Educational Technology Studies, 3(1), 3140. https://doi.org/10.15294/ijcets.v3i1.8683

Marino, M. P., \& Crocco, M. S. (2020). The pre-service practicum experience and inquiryoriented pedagogy: Evidence from student teachers' lesson planning. The Journal of Social Studies Research, 44(1). https://doi.org/10.1016/j.jssr.2019.02.001

Megawati, \& Utami. (2020). English Learning with Powtoon Animation Video. Journal of Education Technology, 4(2), 110. https://doi.org/10.23887/jet.v4i2.25096

Mesters, I., Keulen, H. M. va., de Vries, H., \& Brug, J. (2017). Counselor competence for telephone Motivation Interviewing addressing lifestyle change among Dutch older adults. Evaluation and Program Planning, 65(May), 47-53. https://doi.org/10.1016/j.evalprogplan.2017.06.005

Michelsanti, D., Tan, Z.-H., Sigurdsson, S., \& Jensen, J. (2019). Deep-learning-based audiovisual speech enhancement in presence of Lombard effect. Speech Communication, 115. 
https://doi.org/10.1016/j.specom.2019.10.006

Mukuka, A., Shumba, O., \& Mulenga, H. M. (2021). Students' experiences with remote learning during the COVID-19 school closure: implications for mathematics education. Heliyon, 7(7). https://doi.org/10.1016/j.heliyon.2021.e07523

Nafis, Z. F. N. (2016). Pengembangan Media Pembelajaran Komik Audio Visual Bagi Pembelajaran Ekonomi Materi Kurs Valuta Asing Di Sma Negeri 8 Malang. Jurnal JPE, 9(2). http://journal.um.ac.id/index.php/jpe/article/view/7162

Ntobuo, N. E., Arbie, A., \& Amali, L. N. (2018). The Development of Gravity Comic Learning Media Based on Gorontalo Culture. Jurnal Pendidikan IPA Indonesia, 7(2), 246-251. https://doi.org/10.15294/jpii.v7i2.14344

Partovi, T., \& Razavi, M. R. (2019). The effect of game-based learning on academic achievement motivation of elementary school students. Learning and Motivation, 68. https://doi.org/10.1016/j.lmot.2019.101592

Priantini, D. A. (2020). The Development Of Teaching Video Media Based On Tri Kaya Parisudha In Educational Psychology Courses. Journal of Education Technology, 4(4). https://doi.org/10.23887/jet.v4i4.29608

Rahayuningsih, S. (2020). Animation media of animal husbandry thematic science learning to stimulate scientific attitude in early childhood. International Journal of Scientific and Technology Research. https://doi.org/10.23887/jet.v3i1.17959 Article Metrics

Reis, F., Palermo, T. M., Acalantis, L., Nogueira, L. C., \& Meziat-Filho, N. (2021). "A journey to learn about pain": the development and validation of a comic book about pain neuroscience education for children. Brazilian Journal of Physical Therapy, 2. https://doi.org/10.1016/j.bjpt.2021.04.009

Ristanti, F. F., \& Arianto, F. (2019). Flash Card Media Utilization To Improve Student Activity and Learning Outcomes of Fauna Distribution Subtopic in Class Xi Ips I Sma Xin Zhong Surabaya. Geosfera Indonesia, 4(2), 90. https://doi.org/10.19184/geosi.v4i2.9968

Rosidah, A. (2016). Penerapan Media Pembelajaran Visual Untuk Meningkatkan Pemahaman Konsep Siswa Pada Mata Pelajaran Ips. Jurnal Cakrawala Pendas, 2(2). https://doi.org/10.31949/jcp.v2i2.499

Samsudin, A., Kelana, J. B., \& Muftianti, A. (2019). Utilization of Internet-Based Learning Media in Enhancing Science Literacy Capabilities of Pgsd Students. PrimaryEdu Journal of Primary Education, 3(2), 91. https://doi.org/10.22460/pej.v3i2.1284

Satyawan, V. (2018). The Use Of Animation Video To Teach English At Junior High School Students. Jellt (Journal of English Language and Language Teaching), 2(2), 89-96. https://doi.org/10.36597/jellt.v2i2.3277

Shao, J., \& He, C. (2020). Movie fill in the blank by joint learning from video and text with adaptive temporal attention. Pattern Recognition Letters, 132. https://doi.org/10.1016/j.patrec.2018.06.030

Shohel, M. M. C., \& Kirkwood, A. (2012). Using technology for enhancing teaching and learning in Bangladesh: Challenges and consequences. Learning, Media and Technology, 37(4), 414-428. https://doi.org/10.1080/17439884.2012.671177

Sriani, N. K., Sutama, I. M., \& Darmayanti, I. A. M. (2015). Penerapan Model Pembelajaran Experiential Learning untuk Meningkatkan Kemampuan Menulis Paragraf Deskripsi pada Siswa Kelas VII B SMP Negeri 2Tampaksiring. Jurnal Pendidikan Dan Sastra Indonesia Undiksha, 3(1). https://doi.org/10.23887/jjpbs.v3i1.4776

Sunismi. (2015). Developing Guided Discovery Learning Materials Using Mathematics Mobile Learning Application As An Alternative Media For The Students Calculus II. Cakrawala Pendidikan, 34(3), 334-346. https://journal.uny.ac.id/index.php/cp/article/view/7340/pdf. 
Suryanda, A., Sartono, N., \& Sa'diyah, H. (2019). Developing smartphone-based laboratory manual as a learning media. Journal of Physics: Conference Series, 402. https://doi.org/10.1088/1742-6596/1402/7/077077

Suwana, I. G. G., Artini, L. P., \& Piscayanti, K. S. (2013). The use of R.A.P. paraphrasing strategy to improve students' reading comprehension at class X.A3 in SMKN 2 Singaraja in academic year 2013/2014. Jurnal Pendidikan Bahasa Inggris Undiksha, 1(1). https://doi.org/10.23887/jpbi.v1i1.3859

Suyanto, S. (2018). The Implementation Of The Scientific Approach Through 5ms Of The Revised Curriculum 2013 In Indonesia. Cakrawala Pendidikan, 37(1), 22-29. https://doi.org/10.21831/cp.v37i1.18719

Taufiq, M., Wijayanti, A., \& Fajriah, E. (2020). The implementation of e-comic earth layer to enhance students' self-directed learning. Journal of Physics: Conference Series, 1567, 022070. https://doi.org/10.1088/1742-6596/1567/2/022070

Teng, (Mark) Feng. (2019). The effects of video caption types and advance organizers on incidental L2 collocation learning. Computers \& Education, 142. https://doi.org/10.1016/j.compedu.2019.103655

Thoyyibah, N., Hartono, R., \& Bharati, D. A. L. (2019). The Implementation of Character Education in the English Teaching Learning Using 2013 Curriculum. English Education Journal, 9(2), 254-266. https://doi.org/10.15294/eej.v9i2.30058

Tse, W. S., Choi, L. Y. A., \& Tang, W. S. (2019). Effects of video-based flipped class instruction on subject reading motivation. British Journal of Educational Technology, 50(1), 385-398. https://doi.org/10.1111/bjet.12569

Wiranto, R., \& Slameto, S. (2021). Alumni satisfaction in terms of classroom infrastructure, lecturer professionalism, and curriculum. Heliyon, 7(6). https://doi.org/10.1016/j.heliyon.2021.e06679

Wulandari, I. G. A. A. (2020). Implementation of the 2013 Curriculum Based on a Scientific Approach (Case Study at SD Cluster II Kintamani). International Journal of Elementary Education, 4(3), 422-430. https://doi.org/10.23887/ijee.v4i3.28172

Wusqo, I. U., Khusniati, M., Pamelasari, S. D., Laksono, A., \& Wulandari, D. (2021). The effectiveness of digital science scrapbook on students' science visual literacy. Jurnal Pendidikan IPA Indonesia, 10(1), 121-126. https://doi.org/10.15294/jpii.v10i1.27130

Yuliani, F., Herman, \& Tarmizi, P. (2020). Pengaruh Model Discovery Learning Berbantuan Media Pop-Up Book terhadap Hasil Belajar Tematik Siswa Kelas IV SD Gugus X Kota Bengkulu. Jurnal Riset Pendidikan Dasar, 3(1), 1-8. https://doi.org/10.33369/juridikdas.3.1.1-8

Zhang, D., Zhou, L., Briggs, R. O., \& Nunamaker, J. F. (2016). Instructional video in elearning: Assessing the impact of interactive video on learning effectiveness. Information and Management, 43(1), 15-27. https://doi.org/10.1016/j.im.2005.01.004 